\title{
ESTADO DA ARTE SOBRE TURISMO E CINEMA NO BRASIL: UMA REVISÃO INTEGRATIVA DA LITERATURA ${ }^{1}$
}

\author{
Nathália Körössy \\ Doutora em Desenvolvimento Urbano pela Universidade Federal de Pernambuco (UFPE) \\ Docente do Programa de Pós-graduação em Hotelaria e Turismo (PPHTUR/UFPE) e do Departamento \\ de Hotelaria e Turismo (DHT/UFPE) \\ nathaliakorossy@gmail.com \\ Rute Gabriela dos Santos Paes \\ Bacharel em Turismo pela Universidade Federal de Pernambuco (UFPE) \\ Ex-bolsista Pibic/UFPE/CNPq \\ rgabriela.sp@gmail.com \\ Itamar José Dias e Cordeiro \\ Doutor em Geografia pela Universidade Federal de Pernambuco (UFPE) \\ Docente do Programa de Pós-graduação em Desenvolvimento e Meio Ambiente (Prodema/UFPE) e do \\ Departamento de Hotelaria e Turismo (DHT/UFPE) \\ itamar_cordeiro@yahoo.com.br
}

\section{Resumo}

Objetivo do estudo: Compreender o estado da arte sobre a relação entre turismo e cinema no Brasil. Também buscou mapear dados sobre a situação atual do desenvolvimento do turismo cinematográfico no Brasil, a partir da análise da literatura nacional.

Metodologia/abordagem: A pesquisa tem natureza exploratório-descritiva, com abordagem qualitativa na análise da produção científica nacional sobre turismo e cinema. Como método de pesquisa, selecionou-se a revisão integrativa de literatura. $\mathrm{O}$ levantamento da amostra da pesquisa, composta por artigos científicos que relacionam turismo e cinema e/ou audiovisual, utilizou como base de dados principal o Portal de Periódicos da Coordenação de Aperfeiçoamento de Pessoal de Nível Superior (Capes), tendo-se selecionado o total de 15 artigos científicos, publicados entre 2011 e 2019 em periódicos nacionais indexados nesta base.

Originalidade/Relevância: A relação entre turismo e cinema é crescente no mundo, porém pouco referenciada na literatura nacional. Especificamente sobre turismo cinematográfico, devido à ausência de estudos mais amplos, se desconhece a situação atual desta atividade no Brasil.

Principais resultados: Os estudos brasileiros se concentram em três principais temáticas: cinema como vetor de imagem e promoção de destinos turísticos; análise de imagem e representações de localidades em produções audiovisuais; e turismo cinematográfico em cidades brasileiras. Os achados da pesquisa apontam que o turismo cinematográfico é ainda incipiente no país, sendo a cidade de Cabaceiras (Paraíba) o destino de maior referência neste segmento segundo os autores analisados.

Contribuições teóricas/metodológicas: (i) apresenta um panorama geral dos estudos sobre turismo e cinema publicados em periódicos nacionais; (ii) traça um quadro da situação atual do turismo cinematográfico no Brasil a partir da literatura analisada; (iii) aponta lacunas teórico-empíricas para futuros estudos sobre a temática do turismo e cinema.

${ }^{1}$ Esta pesquisa recebeu recursos do Conselho Nacional de Desenvolvimento Científico e Tecnológico (CNPq) e da Universidade Federal de Pernambuco (UFPE). 
Palavras-chave: Turismo. Cinema. Audiovisual. Turismo cinematográfico no Brasil. Revisão Integrativa da Literatura.

\section{$\underline{\text { Cite como }}$}

American Psychological Association (APA)

Körössy, N., Paes, R. G. dos S., \& Cordeiro, I. J. D. e. (2021, jan./abr.). Estado da arte sobre turismo e cinema no Brasil: uma revisão integrativa da literatura. PODIUM Sport, Leisure and Tourism Review, São Paulo, 10(1), 109-140. https://doi.org/10.5585/podium.v10i1.17212.

\section{Abstract}

\section{STATE OF THE ART ON TOURISM AND CINEMA IN BRAZIL: AN} INTEGRATIVE LITERATURE REVIEW

Objective of the study: To understand the state of the art on the relationship between tourism and cinema in Brazil. It also aims to map information about the current situation of the development of film tourism in Brazil.

Methodology/approach: The research has an exploratory-descriptive nature, with a qualitative approach in the analysis of the national scientific production on tourism and cinema. As a research method, the integrative literature review was selected. The research sample consisted of scientific papers relating tourism and cinema and / or audiovisual published between 2011 and 2019 in national journals indexed in the database of the Portal of Journals of the Coordination for the Improvement of Higher Education Personnel (Capes), having selected a total of 15 scientific papers.

Originality/Relevance: The relationship between tourism and cinema is growing in the world, but little referenced in national literature. Specifically, on film tourism, due to the absence of broader studies, the current situation of this activity in Brazil is unknown.

Main results: Brazilian studies focus on three main themes: cinema as an image vector and promotion of tourist destinations; image analysis and representations of places in audiovisual productions; and film tourism in Brazilian cities. The research findings indicate that film tourism is still incipient in country, with the city of Cabaceiras (Paraíba) being the destination of greatest reference in this segment according to the authors analyzed.

Theoretical/methodological contributions: (i) presents an overview of studies on tourism and cinema published in national journals; (ii) draws a picture of the current situation of film tourism in Brazil from the analyzed literature; (iii) points out theoretical-empirical gaps for future studies on the theme of tourism and cinema.

Keywords: Tourism. Cinema. Audio-visual. Film tourism in Brazil. Integrative Literature Review. 


\section{ESTADO DEL ARTE EN TURISMO Y CINE EN BRASIL: UNA REVISIÓN INTEGRATIVA DE LA LITERATURA}

\section{Resumen}

Objetivo del estudio: Comprender el estado del arte sobre la relación entre turismo y cine en Brasil. A partir del análisis de la literatura nacional, también buscó mapear datos sobre la situación actual del desarrollo del turismo cinematográfico en Brasil.

Metodología/abordaje: La investigación tiene naturaleza exploratoria descriptiva, con un enfoque cualitativo en el análisis de la producción científica nacional sobre turismo y cine. Como método de investigación, se seleccionó la revisión de literatura integradora. La muestra de investigación fue compuesta por artículos científicos que relacionan turismo y cine y / o audiovisual publicados entre 2011 y 2019 en revistas nacionales indexadas en la base de datos del Portal de Publicaciones Periódicas de la Coordinación de Perfeccionamiento del Personal de Nivel de grado y posgrado (Capes). Fueron seleccionados el total de 15 artículos científicos.

Originalidad/Relevancia: La relación entre el turismo y el cine está creciendo en el mundo, pero poco se hace referencia en la literatura nacional. Específicamente en el turismo cinematográfico, debido a la ausencia de estudios más amplios, se desconoce la situación actual de esta actividad en Brasil.

Principales Resultados: Los estudios brasileños se centran en tres temas principales: el cine como vector de imagen y la promoción de destinos turísticos; análisis de imágenes y representaciones de localidades en producciones audiovisuales; y turismo cinematográfico en ciudades brasileñas. Los resultados de la investigación indican que el turismo cinematográfico todavía es incipiente en el país, y la ciudad de Cabaceiras (Paraíba) es el destino de mayor referencia en este segmento según los autores analizados.

Contribuciones teóricas/metodológicas: (i) presenta una visión general de los estudios sobre turismo y cine publicados en revistas nacionales; (ii) dibuja una imagen de la situación actual del turismo cinematográfico en Brasil a partir de la literatura analizada; (iii) señala lagunas teórico-empíricas para futuros estudios sobre el tema del turismo y el cine.

Palabras clave: Turismo. Cine. Audiovisual. Turismo cinematográfico en Brasil. Revisión de literatura integradora.

\section{Introdução}

Filmes para o cinema ou para a televisão, séries, documentários e até mesmo videoclipes são capazes de estimular desejos, novos hábitos de consumo e influenciar o processo de formação e difusão da imagem de lugares. Quando uma localidade é retratada em um filme ou outra obra audiovisual, pode criar no espectador a vontade conhecê-la ou até de vivenciar experiências relacionadas aos personagens, ao roteiro e às locações representadas na produção. 
O audiovisual em geral, e o cinema, em específico ${ }^{2}$, tendem a ser efetivos vetores de imagem e promoção de destinos turísticos, capazes de influenciar turistas no processo decisório para escolha do destino a visitar (Di Cesare \& La Salandra, 2015; Kim \& Kim, 2017; Chen, 2018). Além de divulgar a imagem de uma localidade, as produções audiovisuais influenciam o surgimento de um novo tipo de segmento turístico: o turismo cinematográfico.

O turismo cinematográfico tem como principal motivação a visitação de locais relacionados a determinadas produções audiovisuais, principalmente filmes produzidos para o cinema e séries televisivas (Riley \& Van Doren, 1992; Busby \& Klug, 2001; Macionis, 2004). Segundo Beeton (2006), o turismo cinematográfico pode ocorrer on-location, em locais reais onde cenas específicas das produções audiovisuais são filmadas; e off-location, no caso de atividades em atrações turísticas que são construídas exclusivamente para esse fim, como parques temáticos. O turismo cinematográfico também pode ser caracterizado pela participação em festivais de cinema (Brasil, Mtur, 2007). Em suma, trata-se de uma prática turística cuja motivação principal está ligada ao interesse por obras audiovisuais e por equipamentos ou eventos relacionados.

A relação entre turismo, audiovisual e/ou cinema é uma área ainda pouco examinada no campo do turismo, e os estudos sobre turismo cinematográfico relativamente recentes. $\mathrm{Na}$ década de 1990, Schofield (1996) propôs que as imagens dos turistas contemporâneos seriam moldadas pelo consumo de filmes e televisão sem o viés perceptivo do material promocional; ao passo que Riley, Baker \& Van Doren (1998) se dedicaram a analisar as mudanças do número de visitantes em dez cenários de filmes dos Estados Unidos. A partir dos anos 2000, os estudos se intensificaram. Busby \& Klug (2001) estudaram o perfil dos visitantes em Notting Hill (Londres) após o lançamento do filme Um lugar chamado Notting Hill. Já Kim \& Richardson (2003) exploraram como os filmes Before Sunrise (filmado em Viena) e Groundhog Day (filmado na Pensilvânia) influenciavam a percepção dos turistas sobre um lugar; enquanto que Iwashita (2006) pesquisou o impacto das culturas populares britânicas nos visitantes japoneses no Reino Unido; e Carl, Kindon \& Smith (2007) exploraram a motivação, expectativa e satisfação de turistas ao visitar locações do filme O Senhor dos Anéis.

\footnotetext{
${ }^{2}$ Para fins deste trabalho, entende-se que o audiovisual abrange obras que relacionam sons e imagens em movimento, abarcando não apenas as produções para o cinema, como também para a televisão aberta, televisão fechada e novas mídias (como plataformas de streaming Netflix, Amazon, etc. e Youtube). Abrange formatos como filmes, documentários, telenovelas, séries, videoclipes, entre outros. Observa-se que o turismo se relaciona com todos esses formatos audiovisuais e o termo "turismo cinematográfico" costuma estar associado não apenas às produções cinematográficas, mas também às produções audiovisuais de forma geral, muito embora os estudos turísticos atribuam maior ênfase ao papel do cinema.
} 
Körössy, N., Paes, R. G. dos S., \& Cordeiro, I. J. D. e. (2021, jan./abr.). Estado da arte sobre turismo e cinema no Brasil: uma revisão integrativa da literatura

Desde os pioneiros estudos realizados na década de 1990 até os mais atuais, a produção científica internacional sobre essa temática apresenta uma evolução, embora Hudson \& Ritchie (2006) acreditem que essa produção se encontra relativamente em seu início. Beeton (2010) afirma que as pesquisas feitas sobre o turismo cinematográfico já passaram por uma fase de especulação e justificação da importância do estudo do tema e do conhecimento da atividade, e atualmente se encontram num estágio de refinamento metodológico e de abordagens teóricas. Contudo, a autora se referia aos estudos internacionais de forma geral. No caso brasileiro, não se observa uma sistematização de pesquisas científicas sobre o tema produzidas no país, o que pode levar a um baixo aproveitamento do potencial do turismo cinematográfico nacional. São escassos os estudos sobre a temática e se desconhece a situação atual do desenvolvimento deste segmento no Brasil.

Face ao exposto, a presente pesquisa busca responder aos seguintes questionamentos: Qual o estado da arte sobre turismo e cinema/audiovisual no Brasil? Quais destinos turísticos brasileiros ou produtos turísticos relacionados com turismo cinematográfico são mencionados na literatura nacional? Quais as principais perspectivas para o desenvolvimento do turismo cinematográfico no Brasil? Para tanto, este artigo tem como objetivo compreender o estado da arte sobre a relação entre turismo e cinema/audiovisual no Brasil. Também busca mapear dados sobre a situação atual do desenvolvimento do turismo cinematográfico no Brasil, com o intuito de identificar os principais destinos turísticos brasileiros ou produtos turísticos relacionados com turismo cinematográfico mencionados na literatura nacional, bem como as principais perspectivas para o desenvolvimento do segmento no país.

\section{A relação entre turismo, audiovisual e cinema}

A literatura acadêmica assinala ao menos três pontos de convergência na relação entre turismo, audiovisual e/ou cinema. O primeiro ponto está relacionado aos impactos econômicos diretos e indiretos causados pela recepção e circulação de equipes da produção audiovisual que filmam no destino turístico (Brasil, 2007; Hudson, 2011; Atout France, 2014; Irimias, 2015).

Produtores, diretores, cinegrafistas, atores e técnicos geram demandas de receptivo e preparação dos sets. A partir do momento em que se decide pela filmagem no destino, surgem demandas relacionadas à hospedagem, transporte e alimentação da equipe, visitação de atrativos turísticos, comércio local, costureiras, serviços gerais, entre outras (Brasil, 2007; Hudson, 2011; Beric et al., 2013; Irimias, 2015). Estima-se que durante as filmagens até 60\% 
do orçamento da produção audiovisual sejam investidos na contratação de serviços como hospedagem, alimentação e logística do elenco e equipe de produção (Brasil, 2007), o que gera um retorno financeiro de curto prazo para o destino (Irimias, 2015).

O segundo ponto de convergência relatado na literatura se refere ao audiovisual e ao cinema como vetores da imagem do destino turístico (Beeton, 2000, 2006; Busby \& Klug, 2001; Macionis, 2004). Para Beeton (2006), as imagens veiculadas em produções audiovisuais consistem em importante fator de influência nas decisões de viagens turísticas, com alcance maior que campanhas de marketing tradicional. De igual modo, Di Cesare \& La Salandra (2015) acreditam na relevância das produções audiovisuais enquanto meios de divulgação do destino no âmbito internacional.

Ao difundir a imagem de localidades, o audiovisual acaba muitas vezes influenciando a decisão de viagem do turista por um determinado destino (Beeton, 2000; 2006; Di Cesare \& La Salandra, 2015). Quando a motivação do turista em visitar esse destino está relacionada com a obra audiovisual em si, seu roteiro, suas locações, personagens, etc., surge o turismo cinematográfico - terceiro ponto de convergência na relação entre turismo, audiovisual e cinema (Beeton, 2000; 2006; Busby \& Klug, 2001; Macionis, 2004).

Diversos são os termos empregados pelos estudos internacionais de língua inglesa para se referir ao turismo cinematográfico. Dentre os termos mais comuns destacam-se film tourism (Tooke \& Baker, 1996; Hudson \& Ritchie, 2006; Connell, 2012; Irimias, 2015) e film-induced tourism (Riley \& Van Doren, 1992; Macionis, 2004; Beeton, 2006), mas também observam-se media-induced tourism (Schofield, 1996) e screen tourism (Lundberg et al., 2017).

Riley \& Van Doren (1992) foram os primeiros investigadores a empregar a expressão turismo induzido por filme (film-induced tourism) para designar o aumento do número de visitantes nos destinos devido à influência de filmes. Já Busby \& Klug (2001) recorrem ao termo turismo cinematográfico (film tourism) para expressar um segmento do setor turístico cuja motivação para visitar o destino ou atração reside no fato do mesmo ter aparecido em um filme, vídeo ou televisão. A definição mais adotada no meio acadêmico é a de Beeton (2006) que conceitua o turismo cinematográfico como a visitação a locais onde foram realizadas produções de cinema e TV, a exemplo de locais reais, estúdios de produção e parques temáticos relacionados à produção. A autora também apresenta um conceito de duas vertentes do turismo cinematográfico: on-location, na qual o turismo é realizado em locais reais onde cenas específicas ou elementos de filmes e séries de tv são filmados; e off-location, termo proposto 
Körössy, N., Paes, R. G. dos S., \& Cordeiro, I. J. D. e. (2021, jan./abr.). Estado da arte sobre turismo e cinema no Brasil: uma revisão integrativa da literatura

para exemplificar os casos de atrações turísticas que são construídas para esse fim exclusivamente.

Hudson \& Ritchie (2006), por sua vez, definem turismo cinematográfico como aquele que é gerado pelo resultado da exibição de um destino ou atração no cinema, vídeo ou televisão. Neste mesmo sentido, Macionis (2004) entende turismo cinematográfico como uma experiência pós-moderna do turista em um local que foi retratado em algum meio de comunicação, o que amplia a noção do turismo influenciado pelo cinema para a de turismo influenciado pelo audiovisual. Inicialmente associado ao cinema (Beeton, 2006), o conceito de turismo cinematográfico foi sendo ampliado na medida em que cresceu a influência de outras mídias, passando a incorporar outros tipos de formatos e telas (Azcue, 2014).

Além disso, o conceito de turismo cinematográfico não está apenas associado à motivação principal da viagem. Segundo Azcue (2014) e Qiao, Choib \& Leec (2016), há os turistas que escolhem o destino por outras razões e, uma vez lá, também consomem produtos e experiências turísticas relacionadas ao turismo cinematográfico, como movie maps, roteiros guiados, espaços museais, etc. Nesse sentido, as produções audiovisuais consistem em matérias-primas para criação de novos produtos turísticos que complementam a oferta já existente do destino.

O turismo cinematográfico representa um incremento do fluxo de turistas no destino (Hudson \& Ritchie, 2006; Tuclea \& Nistoreanu, 2011). Segundo Hudson (2011), no Reino Unido, um em cada dez visitantes visualizou previamente o destino em uma produção audiovisual. Um estudo realizado pelo Instituto Francês de Opinião Pública em 2004 (apud Atout France, 2014) identificou que dois terços dos visitantes estrangeiros foram influenciados por algum filme que retratava a França, por exemplo. De acordo com Beeton (2006, 2010), além dos impactos econômicos gerados no destino ao longo do ano, os fluxos turísticos relacionados ao turismo cinematográfico inibem efeitos da sazonalidade.

Com esta perspectiva, o turismo cinematográfico tem sido objeto de atenção por parte de diversos destinos (Tuclea \& Nistoreanu, 2011; Polianskaia et al., 2016). As iniciativas locais estão relacionadas tanto à criação de facilidades para a recepção de produções audiovisuais com o objetivo de servirem como vetores da imagem do destino para atração de visitantes; quanto à criação de novos produtos turísticos. O caminho para tais ações passa pela atuação de organizações de gestão de destino e de film commissions (Connell, 2012), pela colaboração entre os atores públicos e privados (Di Cesare \& La Salandra, 2015) e pela adoção de uma perspectiva de longo prazo (Irimias, 2015). 


\section{Metodologia}

De natureza exploratório-descritiva, esta pesquisa se centra na análise qualitativa da produção científica nacional de modo a conhecer o estado da arte sobre a relação entre turismo e audiovisual/cinema no Brasil. Como método de pesquisa, selecionou-se a revisão integrativa de literatura, por esta permitir conhecer em profundidade a situação atual do conhecimento sobre um determinado tópico. Por buscar a síntese de resultados de pesquisas anteriores, este tipo de revisão fornece um panorama mais amplo sobre uma determinada área do conhecimento (Ercole et al., 2014; Torraco, 2016).

Segundo Torraco (2016), uma revisão de literatura pode ter como principais propósitos: revisar, atualizar e criticar a literatura; conduzir meta-análises da literatura; revisar, criticar e sintetizar a literatura; definir novos conceitos para o tópico em questão; e responder questões específicas de pesquisa sobre o tópico da revisão. Para tal, a revisão integrativa abrange identificação do tema, definição da amostra, categorização dos estudos incluídos, avaliação dos estudos, interpretação dos resultados e síntese do conhecimento encontrado (Torraco, 2016).

O levantamento da amostra da pesquisa, composta por artigos científicos que relacionam turismo e cinema e/ou audiovisual, utilizou como base de dados principal o Portal de Periódicos da Coordenação de Aperfeiçoamento de Pessoal de Nível Superior (Capes), o qual disponibiliza 129 bases referenciais; e, de forma complementar, o portal Publicações de Turismo, da Universidade de São Paulo (USP), que reúne artigos publicados em 36 periódicos científicos ibero-americanos de Turismo.

A coleta de dados foi realizada entre os anos de 2018 e 2019, compreendendo uma busca sistemática dos artigos científicos publicados nos periódicos científicos nacionais indexados em ambas plataformas. No processo de busca, foram empregados os seguintes descritores: <turismo> AND <cinema>, <turismo> AND < audiovisual> (nesses casos, foi empregado no campo de busca o termo booleano "AND”), <turismo cinematográfico>, <cineturismo>. Não foi definido a priori um recorte temporal para a busca, pois a intenção era identificar as publicações mais antigas e as mais atuais sobre a temática.

Para refinar os achados, foram lidos os resumos dos artigos de forma a selecionar apenas aqueles disponíveis em texto completo publicados em periódicos nacionais revisados por pares que relacionassem turismo e audiovisual e/ou cinema como tema principal ou secundário da investigação. Após esse refinamento, chegou-se à amostra de 15 artigos científicos, publicados entre 2011 e 2019 (Quadro 01). 
Körössy, N., Paes, R. G. dos S., \& Cordeiro, I. J. D. e. (2021, jan./abr.). Estado da arte sobre turismo e cinema no Brasil: uma revisão integrativa da literatura

Quadro 01 - Periódicos brasileiros com produção sobre turismo e audiovisual

\begin{tabular}{|l|l|c|c|}
\hline \multicolumn{1}{|c|}{ ISSN } & \multicolumn{1}{|c|}{ Nome do periódico } & $\begin{array}{c}\text { Classificação } \\
\text { Qualis-CAPES } \\
\text { 2013-2016* }\end{array}$ & $\begin{array}{c}\text { Quantidade de } \\
\text { Artigos }\end{array}$ \\
\hline $1677-6976$ & Caderno Virtual de Turismo & B1 & 02 \\
\hline $1983-7151$ & Turismo: Visão e Ação & B1 & 01 \\
\hline $1984-4867$ & Revista Turismo em Análise & B1 & 01 \\
\hline $2178-9061$ & Rosa dos Ventos - Turismo e Hospitalidade & B2 & 03 \\
\hline $2316-932$ X & PODIUM: Sport, Leisure and Tourism Review & B3 & 01 \\
\hline $2357-8211$ & Revista de Turismo Contemporâneo & B3 & 01 \\
\hline $1983-5442$ & Turismo e Sociedade & B4 & 02 \\
\hline $2316-1493$ & Revista Turismo Estudos e Práticas & B4 & 01 \\
\hline $2318-8561$ & Revista Cenário & B4 & 01 \\
\hline $2525-8176$ & Marketing \& Tourism Review & B5 & 02 \\
\hline
\end{tabular}

* Classificação na área de avaliação Administração Pública e de Empresas, Ciências Contábeis e Turismo.

Fonte: Os autores (2019).

A categorização dos artigos consistiu na sistematização de uma planilha Excel contendo: objetivo do artigo, métodos e técnicas da pesquisa, principais resultados, termos empregados em relação a turismo cinematográfico, estudos de casos de turismo cinematográfico citados, principais conclusões. A análise dos artigos buscou enquadrá-los em três categorias segundo o principal enfoque temático do estudo, a saber: audiovisual como vetor de imagem e promoção de destinos turísticos; análise de imagem e representações de localidades em produções audiovisuais; turismo cinematográfico em cidades brasileiras.

Adicionalmente, os artigos foram examinados de modo a responder a duas principais questões que abrangeram a revisão integrativa da literatura: Quais destinos turísticos brasileiros ou produtos turísticos relacionados com turismo cinematográfico são mencionados na literatura nacional? Quais as principais perspectivas para o desenvolvimento do turismo cinematográfico no Brasil? Essas questões foram discutidas a partir da análise dos achados dos artigos de modo a compor a síntese do conhecimento encontrado nesta revisão integrativa da literatura.

\section{Resultados e discussão}

\subsection{Os enfoques dos estudos sobre turismo e audiovisual/cinema no Brasil}

A produção científica brasileira que relaciona turismo e audiovisual é recente, datando de 2011 o primeiro artigo publicado em periódico nacional. Trata-se de uma produção formada majoritariamente por estudos empíricos que abordam o tópico a partir de três principais perspectivas: I) audiovisual (e/ou cinema) como vetor de imagem e promoção de destinos 
turísticos; II) Imagem e representações de localidades em produções audiovisuais; e III) Turismo cinematográfico em cidades brasileiras (quadro 02).

Quadro 02 - Principais enfoques da produção nacional sobre turismo e audiovisual/cinema

\begin{tabular}{|l|c|}
\hline FOCO DO ESTUDO & AUTORES \\
\hline $\begin{array}{l}\text { Audiovisual/Cinema como } \\
\text { vetor de imagem e promoção } \\
\text { de destinos turísticos }\end{array}$ & Silva et al. (2011); Fonseca \& Nunes (2017) \\
\hline $\begin{array}{l}\text { Análise de imagem e e } \\
\text { representações de localidades } \\
\text { em produções audiovisuais }\end{array}$ & $\begin{array}{c}\text { Yasoshima (2012); Godoy \& Luna (2012); Vila, } \\
\text { Nogueira \& Lopes (2017); Lopes, Nogueira \& Baptista } \\
\text { (2017); Santos, Alencar \& Neves (2018); Freitas \& Gotardo } \\
\text { (2018); Lima \& Silva (2019) }\end{array}$ \\
\hline $\begin{array}{l}\text { Turismo cinematográfico em } \\
\text { cidades brasileiras }\end{array}$ & $\begin{array}{c}\text { Costa (2016); Duarte e Fonseca Filho (2016); Souza } \\
\text { e Silva (2016); Silveira \& Baptista (2017) }\end{array}$ \\
\hline
\end{tabular}

Fonte: Os autores (2019).

Do ponto de vista quantitativo, constata-se que o maior volume de estudos versa sobre imagem e representações de localidades em produções audiovisuais (5 artigos), seguido pelos estudos que analisam casos de turismo cinematográfico em cidades brasileiras (4 artigos) e pelas pesquisas que abordam o papel do cinema como vetor de imagem e promoção turística (2 artigos).

\subsubsection{Os estudos sobre o cinema e/ou audiovisual como vetor de imagem e promoção de destinos turísticos}

Tendo como foco da pesquisa o papel do cinema enquanto vetor de imagem e de promoção de destinos turísticos, Silva et al. (2011) e Fonseca \& Nunes (2017) apontam que produções cinematográficas filmadas em destinos turísticos têm a capacidade de despertar o interesse do consumidor em visitar a localidade retratada na produção.

Para Silva et al. (2011), o turista, antes mesmo de viajar, compra uma imagem sobre a localidade que pretende visitar, o que a torna um importante fator determinante no processo de tomada de decisão por um destino. Para defender esse argumento, os autores aplicaram uma survey com 30 turistas na cidade de Parnaíba (PI) em 2011. Quase a totalidade da amostra (29 respondentes) revelou que já sentiu o desejo de viajar após assistir a um filme, fazendo com que os autores defendam a ideia de que o cinema pode se converter em meio de motivação para 
Körössy, N., Paes, R. G. dos S., \& Cordeiro, I. J. D. e. (2021, jan./abr.). Estado da arte sobre turismo e cinema no Brasil: uma revisão integrativa da literatura

o turismo, podendo ser instrumentalizado para a promoção e comercialização de destinos turísticos.

Com essa mesma perspectiva, Fonseca \& Nunes (2017) demonstraram que características de um destino turístico reveladas por meio de uma produção cinematográfica podem despertar nos espectadores interesse de visitação. Por meio da aplicação, em 2014, de uma survey online com 113 respondentes, os autores verificaram que 79,3\% dos consumidores apontaram um destino turístico que gostariam de visitar devido à sua exposição em uma produção cinematográfica. Dentre os destinos mais desejados, destacam-se a Nova Zelândia $(14,2 \%)$, Nova Iorque $(8,8 \%)$ e Los Angeles (4,4\%). Segundo os autores, esses destinos correspondem aos principais destinos mundiais no âmbito do turismo cinematográfico.

Ambos os estudos concluem que não apenas filmes, mas também outras produções audiovisuais como séries e novelas, podem influenciar positivamente na escolha do consumidor por visitar um determinado destino turístico, na medida em que expõem atrativos naturais e culturais da localidade. Nesse sentido, ressaltam a importância da imagem transmitida nas produções enquanto um meio de promoção do destino turístico.

O quadro 03 sintetiza os principais achados desses estudos: 
Körössy, N., Paes, R. G. dos S., \& Cordeiro, I. J. D. e. (2021, jan./abr.). Estado da arte sobre turismo e cinema no Brasil: uma revisão integrativa da literatura

Quadro 03 - Síntese dos estudos sobre cinema como vetor de imagem e promoção de destinos turísticos

\begin{tabular}{|c|c|c|c|}
\hline AUTORES & OBJETIVO & $\begin{array}{c}\text { MÉTODOS } \\
\text { EMPREGADOS }\end{array}$ & PRINCIPAIS CONCLUSÕES \\
\hline $\begin{array}{l}\text { Silva et al. } \\
(2011)\end{array}$ & $\begin{array}{l}\text { Diagnosticar a } \\
\text { influência da } \\
\text { produção } \\
\text { cinematográfica Sete } \\
\text { anos no Tibete na } \\
\text { escolha de destinos } \\
\text { turísticos. }\end{array}$ & $\begin{array}{l}\text { Pesquisa } \\
\text { quantitativa. } \\
\text { Aplicação de } \\
\text { questionários } \\
\text { com turistas. }\end{array}$ & $\begin{array}{l}\text { - A imagem, incluindo a imagem } \\
\text { exibida pelo cinema, é um fator } \\
\text { determinante na escolha de } \\
\text { destinos turísticos. } \\
\text { A exibição de atrativos turísticos } \\
\text { em produções cinematográficas } \\
\text { pode gerar aumento no número de } \\
\text { turistas nas localidades filmadas. } \\
\text { Necessidade de estudos sobre a } \\
\text { imagem do Brasil nas produções } \\
\text { audiovisuais como fatores de } \\
\text { motivação para visitação. }\end{array}$ \\
\hline $\begin{array}{l}\text { Fonseca \& } \\
\text { Nunes } \\
(2017)\end{array}$ & $\begin{array}{l}\text { Entender em que } \\
\text { medida as produções } \\
\text { cinematográficas } \\
\text { realizadas num } \\
\text { destino turístico } \\
\text { podem despertar o } \\
\text { interesse por parte } \\
\text { dos consumidores } \\
\text { pelo destino } \\
\text { retratado. }\end{array}$ & $\begin{array}{l}\text { Pesquisa } \\
\text { quantitativa. } \\
\text { Aplicação de } \\
\text { questionários } \\
\text { (survey online) } \\
\text { com turistas em } \\
\text { potencial. }\end{array}$ & $\begin{array}{l}\text { - Turismo cinematográfico é uma } \\
\text { atividade de grande importância } \\
\text { econômica para os destinos } \\
\text { turísticos. } \\
\text { As produções cinematográficas } \\
\text { podem influenciar positivamente } \\
\text { na escolha do consumidor. } \\
\text { Necessidade de se definir } \\
\text { estratégias de promoção e } \\
\text { comercialização que levem os } \\
\text { consumidores a praticar turismo } \\
\text { cinematográfico. } \\
\text { Nova Zelândia, Reino Unido, } \\
\text { França, Austrália, Canadá, } \\
\text { Estados Unidos são exemplos de } \\
\text { emprego do audiovisual na } \\
\text { promoção turística e de turismo } \\
\text { cinematográfico. }\end{array}$ \\
\hline
\end{tabular}

Fonte: Os autores (2019).

\subsubsection{Os estudos com foco na análise da imagem e de representações de localidades em produções audiovisuais}

Esses estudos aprofundam o entendimento do audiovisual como vetor de imagem ao proporem análises de imagem e representações de destinos turísticos retratados em produções audiovisuais.

O estudo de Godoy \& Luna (2012) focou na análise do imaginário sobre as favelas, buscando relacionar o cinema brasileiro e a expansão do turismo em favelas no Rio de Janeiro. Partiram da ideia de que o cinema influencia o imaginário das pessoas, criando e recriando estéticas, sendo algumas das quais apropriadas pela atividade turística. Considerando o cinema elemento fundamental para se refletir sobre o turismo em favela, as autoras afirmam existir uma relação entre a estética do cinema e a estética do produto "turismo na favela" na medida em que 
Körössy, N., Paes, R. G. dos S., \& Cordeiro, I. J. D. e. (2021, jan./abr.). Estado da arte sobre turismo e cinema no Brasil: uma revisão integrativa da literatura

a favela retratada no cinema (a favela cinematográfica) se assemelha com as formas de turismo que ocorrem na favela (a favela turística).

Ao realizarem observação em reality tours na Favela da Rocinha e na Vila Canoas (ambas no Rio de Janeiro), as autoras observaram a presença de vários elementos das produções cinematográficas nos circuitos, como casas, becos, ruelas e bares. Para as autoras, a favela retratada em filmes como Cidade de Deus (direção de Fernando Meirelles e Kátia Lund, 2002), Orfeu (direção de Cacá Diegues, 1999), Maré, nossa história de amor (direção de Lúcia Murat, 2007) e Tropa de Elite 2 - O inimigo agora é outro (direção de José Padilha, 2010) que compõem o cinema brasileiro da Retomada pós década de 1990, mostram uma "violência lúdica" que, ao invés de contribuir para uma imagem negativa, incorpora a favela ao imaginário turístico. E, se os planejadores turísticos concebem os produtos de acordo com o que emerge do imaginário turístico, o imaginário da favela turística acaba indo ao encontro do imaginário da favela cinematográfica.

Já Vila, Brea \& Garcia (2012) analisaram a imagem relacionada ao turismo termal difundida em produções audiovisuais e a forma como essa imagem é associada à promoção de destinos. Para isso, analisaram duas séries televisivas espanholas (Hospital Central e Padre Casares) que tiveram episódios filmados na cidade de Ourense, conhecido destino de turismo termal espanhol. Constataram que as séries associaram a imagem da cidade a um destino de termalismo e saúde, tendo sido representados atrativos como fontes de águas medicinais e zonas termais.

Como resultado da difusão desse tipo de imagem, os autores atribuem a essas produções audiovisuais o incremento do fluxo turístico e número de pernoites no destino entre os anos 2006 e 2010. Concluem que o uso de séries de ficção para difusão da imagem de destinos turísticos é uma ferramenta eficaz de promoção turística. Nesse sentido, acreditam que quanto maior a audiência, maior o impacto sobre o destino.

Com a mesma linha de abordagem, Pereira Neto \& Schmidlin (2013) analisaram a imagem do Nordeste brasileiro nas produções cinematográficas nacionais e sua influência no turismo da região. Para tanto, a pesquisa focou na imagem percebida de 70 estudantes de cinema do Ceará sobre o Nordeste em obras cinematográficas nacionais. Buscou apreender dos estudantes se a imagem percebida poderia gerar interesse de visitação da região.

Os autores verificaram que embora a imagem de seca e miséria no Nordeste ainda seja amplamente difundida no cinema nacional, nos casos em que a trama se passa na atualidade são retratadas características populares de aspectos mais cômicos. Mesmo assim, concluíram que 
há certa invariabilidade nas representações nordestinas, o que tende a limitar o imaginário do público a poucas percepções sobre a região.

Pereira Neto \& Schmidlin (2013) também identificaram que o interesse pela visitação da região gerado a partir da sua imagem retratada na produção cinematográfica nacional foi influenciado de forma negativa, pois $61 \%$ dos informantes responderam que não visitariam a região. Os autores atribuem esse número justamente à imagem de miséria e seca que frequentemente é retratada pelo cinema. Ainda que esse resultado possa ser interpretado como tendencioso, considerando a limitada amostra da pesquisa, serve de alerta para a influência negativa que o cinema pode exercer no imaginário popular de uma localidade.

Por sua vez, Nogueira \& Lopes (2017) analisaram o filme de animação Rio 2 (direção de Carlos Saldanha, 2014), de modo a identificar clichês associados ao imaginário sobre o Brasil de forma geral e, de forma específica, sobre a Amazônia e a cidade do Rio de Janeiro. Os autores constataram que o filme reproduz estereótipos já consolidados no imaginário sobre o país.

Tendo também como foco da análise o filme de animação Rio 2 (direção de Carlos Saldanha, 2014), o estudo de Lopes, Nogueira \& Batista (2017) relaciona as representações da cidade do Rio de Janeiro e da floresta Amazônica com as estratégias de promoção do turismo e dos megaeventos que ocorreram no Brasil (Copa FIFA 2014 e Olimpíadas 2015). Sequência da animação Rio, o filme é uma produção hollywoodiana, dirigido por um realizador brasileiro. Segundo os autores, o filme cria uma imagem do Rio de Janeiro e da Amazônia baseada em clichês culturais e estereótipos sociais. Concluem que o filme, mesmo mostrando aspectos negativos sobre o país (por exemplo, o tráfico de animais e o desmatamento), contribui para gerar uma imagem positiva do Brasil, com um clima festivo e feliz, podendo influenciar na escolha de destinos de viagem.

Com atenção às representações da gastronomia, Santos, Alencar \& Neves (2018) realizaram uma análise do filme Estômago (direção de Marcos Jorge, 2007), rodado na cidade de Curitiba (Paraná). A pesquisa buscou analisar a representação da cidade, com ênfase na gastronomia, ao entender o filme como um elemento simbólico capaz de atrair visitantes às localidades. Segundo os autores, o filme apresenta imagens de lugares tradicionais da cidade, como o mercado municipal e bares ligados afetivamente com a gastronomia local. Os autores concluem que o filme retrata a cidade de Curitiba como um ambiente estimulante à cultura.

A pesquisa de Lima \& Silva (2019) se centrou no imaginário turístico do estado do Rio Grande do Norte enquanto destino turístico, por meio da análise de telenovelas da Rede Globo 
e do SBT que foram rodadas na localidade entre 1986 e 2016. Com uma abordagem qualitativa, os autores analisaram oito telenovelas gravadas no estado, tendo identificado que o imaginário formado a partir dessas produções audiovisuais nem sempre remeteu ao próprio estado, uma vez que algumas produções não relacionaram os cenários e locações ao nome real do destino onde foram gravadas.

Já as produções que efetivamente relacionaram a trama ao Rio Grande do Norte evidenciaram um destino turístico de sol e praia, tendo retratado poucos elementos culturais e históricos da localidade. Os autores concluíram que, apesar das telenovelas serem uma importante estratégia de promoção turística, no caso do Rio Grande do Norte, elas limitaram o imaginário do estado ao se concentrarem mais em locações relacionadas à praia e a tramas românticas.

Freitas \& Gotardo (2018) analisaram a imagem da cidade do Rio de Janeiro retratada em produções audiovisuais da China veiculadas no YouTube para a ocasião dos Jogos Olímpicos de 2016. Foram analisadas onze matérias produzidas pelo site taiwanês TomoNews, publicadas em seu canal em agosto de 2016. Os autores constataram que mesmo diante dos esforços de city branding para consolidação da marca turística Rio, a imagem retratada nessas produções estava relacionada à descrença de que a cidade estaria preparada para sediar o megaevento. Para os autores, prevaleceu a imagem de uma cidade ligada à violência e a epidemias como a relacionada ao vírus da Zika.

Por fim, o estudo de Yasoshima (2012) não abordou representações de localidades, tendo focado especificamente na imagem da gastronomia. $\mathrm{O}$ autor centrou-se em filmes gastronômicos (food films), buscando identificar as suas principais características e representações relacionadas com a gastronomia. Para o autor, as representações de comida nas produções cinematográficas abrangem diversas temáticas e valorizam a gastronomia. Defende que os food films atuam para despertar o interesse do público espectador e aponta que o chef de cozinha costuma ser estereotipado nos filmes como uma figura de poder e glamour, não correspondendo à realidade em geral. Por fim, Yasoshima (2012) conclui que esse tipo de filme resulta na preservação das cozinhas regionais, uma vez que retrata a comida, o seu modo de preparo, os ingredientes, etc. como formas de estimular o gosto do espectador.

O quadro 04 sintetiza os principais achados dos estudos: 
Quadro 04 - Síntese dos estudos sobre imagem e representações de localidades em produções audiovisuais

Continua

\begin{tabular}{|c|c|c|c|}
\hline AUTORES & OBJETIVO & $\begin{array}{c}\text { MÉTODOS } \\
\text { EMPREGADOS }\end{array}$ & PRINCIPAIS CONCLUSÕES \\
\hline $\begin{array}{l}\text { Godoy \& } \\
\text { Luna } \\
\text { (2012) }\end{array}$ & $\begin{array}{l}\text { Estabelecer a relação } \\
\text { entre o cinema e o } \\
\text { turismo, analisando } \\
\text { seus pontos de } \\
\text { convergência e discutir } \\
\text { a problemática que } \\
\text { envolve os reality } \\
\text { tours, destacando o } \\
\text { produto turístico } \\
\text { designado como } \\
\text { "turismo em favelas", } \\
\text { retratado em filmes } \\
\text { brasileiros. }\end{array}$ & $\begin{array}{l}\text { Pesquisa } \\
\text { qualitativa no } \\
\text { campo da } \\
\text { Estética. Estudo } \\
\text { de caso na Favela } \\
\text { da Rocinha e } \\
\text { Vila Canoas (Rio } \\
\text { de Janeiro) }\end{array}$ & $\begin{array}{l}\text { - A imagem da favela retratada no cinema brasileiro } \\
\text { a partir dos anos } 1990 \text { (a favela cinematográfica) } \\
\text { influencia a construção do imaginário turístico } \\
\text { sobre a favela e consequente formação da favela } \\
\text { turística (o produto turístico 'turismo em favela'). } \\
\text { - A estética turística e a estética cinematográfica da } \\
\text { favela se tornam suportes de uma autenticidade } \\
\text { construída. }\end{array}$ \\
\hline $\begin{array}{l}\text { Vila, Brea } \\
\text { \& Garcia } \\
(2012)\end{array}$ & $\begin{array}{l}\text { Analisar a imagem de } \\
\text { um destino termal } \\
\text { (cidade de Ourense, } \\
\text { Espanha) por meio da } \\
\text { análise de duas sérias } \\
\text { de ficção filmadas na } \\
\text { cidade e analisar o } \\
\text { impacto no turismo } \\
\text { local em número de } \\
\text { visitantes e pernoites. }\end{array}$ & $\begin{array}{l}\text { Análise de } \\
\text { conteúdo. } \\
\text { Pesquisa } \\
\text { quantitativa. } \\
\text { Estudo de caso } \\
\text { em Ourense. }\end{array}$ & $\begin{array}{l}\text { - O uso de séries de ficção para difusão da imagem } \\
\text { de destinos turísticos é uma ferramenta eficaz de } \\
\text { promoção turística. } \\
\text { - Quanto maior a audiência, maior impacto a } \\
\text { produção audiovisual gera no destino turístico. } \\
\text { O setor turístico termal e o setor audiovisual } \\
\text { possuem sinergias que potencializam a promoção } \\
\text { de destinos turísticos termais. }\end{array}$ \\
\hline $\begin{array}{l}\text { Yasoshima } \\
(2012)\end{array}$ & $\begin{array}{l}\text { Analisar filmes } \\
\text { gastronômicos } \\
\text { procurando as suas } \\
\text { principais } \\
\text { características } \\
\text { relacionadas com a } \\
\text { gastronomia. }\end{array}$ & $\begin{array}{l}\text { Pesquisa } \\
\text { documental. } \\
\text { Análise fílmica. }\end{array}$ & $\begin{array}{l}\text { - As representações da comida no cinema abrangem } \\
\text { diversos subtemas e servem para valorizar a } \\
\text { gastronomia e suas relações sociais e culturais, } \\
\text { conseguindo despertar o interesse do espectador } \\
\text { pela cozinha. } \\
\text { Os filmes gastronômicos são responsáveis pela } \\
\text { preservação das cozinhas regionais, mostrando a } \\
\text { comida, seu modo de preparo, ingredientes, etc. } \\
\text { como formas de estimular o gosto do espectador. }\end{array}$ \\
\hline $\begin{array}{l}\text { Pereira } \\
\text { Neto \& } \\
\text { Schmidlin } \\
(2013)\end{array}$ & $\begin{array}{l}\text { Analisar a imagem do } \\
\text { nordeste brasileiro } \\
\text { veiculada na produção } \\
\text { cinematográfica } \\
\text { nacional e relacioná-la } \\
\text { com o turismo na } \\
\text { região. }\end{array}$ & $\begin{array}{l}\text { Pesquisa quali- } \\
\text { quantitativa. } \\
\text { Aplicação de } \\
\text { questionários } \\
\text { com estudantes } \\
\text { de cinema do } \\
\text { Ceará (survey } \\
\text { online). }\end{array}$ & $\begin{array}{l}\text { - A incipiente atividade cinematográfica brasileira se } \\
\text { mostra pouco forte para gerar interesse de visitação } \\
\text { em localidades brasileiras. } \\
\text { Roteiros rasos e não diversificados limitam o } \\
\text { desenvolvimento do turismo cinematográfico no } \\
\text { Brasil e o setor audiovisual como ferramenta de } \\
\text { marketing turístico. } \\
\text { A imagem do Nordeste disseminada nas produções } \\
\text { cinematográficas brasileiras pouco aproveita a } \\
\text { variedade de riquezas e diferentes facetas da região. } \\
\text { O Nordeste retratado como um lugar seco, } \\
\text { miserável e de características naturalistas, com } \\
\text { personagens caricatos, mostra-se como uma } \\
\text { imagem não atrativa para o turismo. }\end{array}$ \\
\hline
\end{tabular}


Conclusão

\begin{tabular}{|c|c|c|c|}
\hline AUTORES & OBJETIVO & $\begin{array}{c}\text { MÉTODOS } \\
\text { EMPREGADOS }\end{array}$ & PRINCIPAIS CONCLUSÕES \\
\hline $\begin{array}{l}\text { Nogueira \& } \\
\text { Lopes } \\
(2017)\end{array}$ & $\begin{array}{l}\text { Refletir acerca de } \\
\text { clichês associados ao } \\
\text { imaginário sobre o } \\
\text { Brasil, especialmente, } \\
\text { ao Rio de Janeiro e à } \\
\text { Amazônia, a partir de } \\
\text { análise do filme de } \\
\text { animação Rio2. }\end{array}$ & $\begin{array}{l}\text { Pesquisa } \\
\text { bibliográfica. } \\
\text { Análise de } \\
\text { imagem. }\end{array}$ & $\begin{array}{l}\text { - A produção audiovisual pode ser um instrumento } \\
\text { de promoção turística em função de sua mensagem } \\
\text { implícita na representação dos lugares ambientados } \\
\text { na produção. } \\
\text { A imagem do Rio de Janeiro e da Amazônia } \\
\text { retratada em Rio2 limita a compreensão do Brasil e } \\
\text { reforça preconceitos e estereótipos. }\end{array}$ \\
\hline $\begin{array}{l}\text { Lopes, } \\
\text { Nogueira \& } \\
\text { Batista } \\
(2017)\end{array}$ & $\begin{array}{l}\text { Refletir acerca de } \\
\text { clichês associados ao } \\
\text { imaginário sobre o } \\
\text { Brasil, especialmente, } \\
\text { ao Rio de Janeiro e à } \\
\text { Amazônia, a partir de } \\
\text { cenas do filme de } \\
\text { animação Rio2 }\end{array}$ & $\begin{array}{l}\text { Pesquisa } \\
\text { bibliográfica. } \\
\text { Análise de } \\
\text { imagem. }\end{array}$ & $\begin{array}{l}\text { - Rio2 reproduz estereótipos e apresenta aspectos de } \\
\text { promoção do turismo e megaeventos. } \\
\text { Produções audiovisuais, incluindo animações } \\
\text { infantis, podem ser consideradas um produto } \\
\text { ideológico e estratégico sob a égide capitalista. }\end{array}$ \\
\hline $\begin{array}{l}\text { Santos, } \\
\text { Alencar \& } \\
\text { Neves } \\
(2018)\end{array}$ & $\begin{array}{l}\text { Analisar a } \\
\text { representação das } \\
\text { cidades criativas em } \\
\text { cooperação com a } \\
\text { indústria criativa do } \\
\text { audiovisual, com } \\
\text { ênfase na gastronomia } \\
\text { do filme "Estômago" } \\
\text { na cidade de Curitiba- } \\
\text { PR. }\end{array}$ & $\begin{array}{l}\text { Pesquisa } \\
\text { qualitativa. } \\
\text { Pesquisa } \\
\text { bibliográfica. } \\
\text { Análise de } \\
\text { imagem. } \\
\text { Emparelhamento } \\
\text { de dados. }\end{array}$ & $\begin{array}{l}\text { - A articulação entre cidade criativa e setor } \\
\text { audiovisual em Curitiba pode gerar vantagens } \\
\text { competitivas frente a outros destinos, geração de } \\
\text { empregos em setores da economia criativa e a } \\
\text { promoção da cidade por meio da gastronomia e da } \\
\text { produção cinematográfica. } \\
\text { As cidades criativas incorporam a cultura no } \\
\text { planejamento urbano e na forma como a cidade } \\
\text { funciona, dando espaço para as indústrias criativas } \\
\text { se desenvolverem. } \\
\text { As relações estabelecidas entre cidade, gestores, } \\
\text { empresas, gastronomia e o audiovisual são } \\
\text { elementos que trazem vantagens competitivas } \\
\text { frente a outros destinos e outros benefícios à cidade. }\end{array}$ \\
\hline $\begin{array}{l}\text { Lima \& } \\
\text { Silva } \\
(2019)\end{array}$ & $\begin{array}{l}\text { Apresentar os } \\
\text { elementos que } \\
\text { compõem a imagem e o } \\
\text { imaginário turístico do } \\
\text { destino Rio Grande do } \\
\text { Norte a partir das } \\
\text { telenovelas da Rede } \\
\text { Globo e do SBT (1986- } \\
\text { 2016). }\end{array}$ & $\begin{array}{l}\text { Pesquisa } \\
\text { qualitativa. } \\
\text { Análise } \\
\text { documental. } \\
\text { Análise de } \\
\text { imagem. }\end{array}$ & $\begin{array}{l}\text { - As telenovelas gravadas no Rio Grande do Norte } \\
\text { contribuíram para a construção de imaginário que } \\
\text { nem sempre remete ao estado. } \\
\text { Nas situações nas quais as telenovelas apontaram } \\
\text { Rio Grande do Norte como local da trama, } \\
\text { evidenciou-se um destino de sol e praia, com } \\
\text { poucos elementos culturais e históricos, tendo foco } \\
\text { principalmente em casais em situações românticas. } \\
\text { Embora importante maneira de divulgação do Rio } \\
\text { Grande do Norte como destino turístico, as } \\
\text { telenovelas limitaram o imaginário da localidade. }\end{array}$ \\
\hline $\begin{array}{l}\text { Freitas \& } \\
\text { Gotardo } \\
(2018)\end{array}$ & $\begin{array}{l}\text { Analisar variáveis da } \\
\text { imagem da cidade do } \\
\text { Rio de Janeiro em } \\
\text { produções audiovisuais } \\
\text { da República da China } \\
\text { (re)apresentadas no } \\
\text { YouTube no dia da } \\
\text { abertura dos Jogos } \\
\text { Olímpicos de } 2016 .\end{array}$ & $\begin{array}{l}\text { Análise de } \\
\text { imagem. }\end{array}$ & $\begin{array}{l}\text { - Apesar dos esforços do city branding na construção } \\
\text { da marca Rio, as emissões analisadas demonstram } \\
\text { uma descrença de que a cidade estaria preparada } \\
\text { para receber os Jogos Olímpicos de 2016, } \\
\text { especialmente devido às possíveis epidemias e à } \\
\text { violência. } \\
\text { Evidencia-se um apelo a emoções negativas - nojo, } \\
\text { medo, sexualização - na construção da imagem do } \\
\text { Rio de Janeiro. }\end{array}$ \\
\hline
\end{tabular}

Fonte: Os autores (2019). 


\subsubsection{Os estudos sobre turismo cinematográfico em cidades brasileiras}

Os trabalhos de Costa (2016), Duarte e Fonseca Filho (2016), Souza e Silva (2016) e Silveira \& Baptista (2017) focaram em estudos de caso sobre o desenvolvimento do turismo cinematográfico em localidades brasileiras (quadro 05).

Quadro 05 - Os estudos de caso sobre turismo cinematográfico em localidades brasileiras

\begin{tabular}{|c|c|c|}
\hline AUTORES & $\begin{array}{c}\text { LOCALIDADES } \\
\text { INVESTIGADAS NO ESTUDO } \\
\text { DE CASO }\end{array}$ & OBJETIVO DA PESQUISA \\
\hline Costa (2016) & Belém do Pará & $\begin{array}{l}\text { Analisar como o turismo } \\
\text { cinematográfico pode ser } \\
\text { implementado em Belém do Pará. }\end{array}$ \\
\hline Duarte \& Fonseca Filho (2016) & Niterói & $\begin{array}{l}\text { Apresentar a cidade de Niterói } \\
\text { como um destino } \\
\text { cinematográfico e construir um } \\
\text { catálogo de locações de atrativos, } \\
\text { para mostrar potencial para } \\
\text { produção audiovisual, através de } \\
\text { um levantamento de atrativos } \\
\text { turísticos da cidade. }\end{array}$ \\
\hline Souza \& Silva (2016) & Cabaceiras & $\begin{array}{l}\text { Analisar a influência do cinema } \\
\text { para alavancagem do turismo na } \\
\text { cidade de Cabaceira, na Paraíba, } \\
\text { a partir da inserção do município } \\
\text { como locação na produção } \\
\text { cinematográfica nacional. }\end{array}$ \\
\hline Silveira \& Baptista (2017) & Garibaldi & $\begin{array}{l}\text { Abordar a relação existente entre } \\
\text { cinema e turismo, tendo como } \\
\text { lócus de análise a cidade de } \\
\text { Garibaldi, localizada na Serra } \\
\text { Gaúcha. }\end{array}$ \\
\hline
\end{tabular}

Fonte: Os autores (2019).

Costa (2016) analisou as potencialidades de desenvolvimento do turismo cinematográfico na cidade de Belém do Pará. O autor identificou possibilidades de locações a serem usadas em produções audiovisuais na cidade. Identificou que muitas dessas possíveis locações já são atrativos turísticos consolidados da cidade, como, por exemplo, o Theatro da Paz, a Estação das Docas e o Parque Mangal das Garças. Segundo Costa (2016), esses atrativos turísticos já serviram de cenário para a produção de filmes, novelas, documentários e publicidades por serem representativos do cotidiano da região amazônica, muito embora acredite que o turismo cinematográfico não seja uma realidade na cidade. O autor relata que a cidade não conta com nenhuma iniciativa do poder público no sentido de fomentar a relação 
entre turismo e cinema. Por isso, conclui que para se posicionar Belém do Pará como destino de referência de turismo cinematográfico, seria necessária a atuação de agentes públicos e privados no fomento do setor audiovisual, por meio de apoio financeiro e fiscal, bem como recomenda a criação de uma film commission.

A pesquisa de Duarte \& Fonseca Filho (2016) também segue a mesma perspectiva de apresentar as potencialidades para o desenvolvimento do turismo cinematográfico em uma localidade específica. Tendo como caso de estudo a cidade de Niterói, os autores apresentam um catálogo de locações a partir da análise de atrativos capazes de expressar a identidade da cidade. Com a criação de tal catálogo, os autores esperam contribuir como fonte de informação para futuras iniciativas de captação de produções audiovisuais.

Para tal, Duarte \& Fonseca Filho (2016) realizaram registros fotográficos dos principais atrativos de Niterói. A identificação dos atrativos partiu de um estudo de demanda turística prévio, o qual apontava os principais atrativos turísticos mencionados pelos turistas. Os autores concluem que a cidade tem potencial para diversificar o turismo local por meio da formatação de uma oferta turística relacionada com o audiovisual, visto que a cidade já foi cenário de diversas produções audiovisuais. Apontam como caminho a criação de incentivos fiscais, a criação de uma film commission para captação de novas produções e o estabelecimento de parcerias com entidades locais.

Diferentemente dos trabalhos anteriormente citados, as pesquisas de Souza \& Silva (2016) e de Silveira \& Baptista (2017) abordam a relação entre cinema e turismo em localidades onde essa relação já se mostra mais evidente por meio de iniciativas institucionais de promoção do turismo cinematográfico. Souza \& Silva (2016) focaram no estudo de caso da cidade de Cabaceiras (Paraíba), enquanto que Silveira \& Baptista (2017) analisaram o desenvolvimento do turismo cinematográfico na cidade de Garibaldi (Rio Grande do Sul).

Souza e Silva (2016) analisaram a influência do cinema no desenvolvimento do turismo na cidade de Cabaceiras, situada no sertão da Paraíba. A cidade de pouco mais de 5 mil habitantes é considerada a "Roliúde Nordestina", por já ter recebido mais de 20 produções cinematográficas nacionais, dentre as quais: O Auto da Compadecida (direção de Guel Arraes, 2000), Cinema, Aspirinas e Urubus (direção de Marcelo Gomes, 2005), Canta Maria (direção de Francisco Ramalho Júnior, 2006) e Romance (direção de Guel Arraes, 2008). Segundo os autores, fatores como a boa luminosidade, baixo índice pluviométrico e paisagens peculiares

\footnotetext{
${ }^{3}$ Em alusão a Hollywood, distrito da cidade norte-americana de Los Angeles, caracterizado pela alta concentração de empresas do ramo cinematográfico e referência do cinema mundial.
} 
despertaram o interesse de cineastas em usar a cidade como locação de suas produções (Souza e Silva, 2016).

A pesquisa se baseou na aplicação de questionários com 60 pessoas (das quais, 10 empresários, 20 residentes e 30 visitantes) e identificou que tanto o turismo como o cinema exercem influência no desenvolvimento da cidade, gerando benefícios como melhorias nas estruturas de acesso, saneamento, saúde e educação. Souza e Silva (2016) identificaram que os principais atrativos da cidade eram justamente os cenários retratados nos filmes, muito embora tenham percebido que os turistas que visitavam tais locações não necessariamente as associavam às produções cinematográficas realizadas na cidade. Com tal perspectiva, concluíram que na cidade de Cabaceiras a interface entre turismo e cinema existe, embora acreditem que o turismo cinematográfico não seja consolidado.

Por sua vez, Silveira \& Baptista (2017) analisaram o caso da cidade gaúcha de Garibaldi enquanto destino onde o turismo cinematográfico já se mostra em desenvolvimento. Segundo os autores, Garibaldi tem se destacado tanto no cenário audiovisual nacional, devido ao número de produções que tem conseguido atrair para a região, como também no campo do turismo cinematográfico devido à criação de produtos turísticos relacionados ao cinema.

No campo audiovisual, Garibaldi foi cenário de diversas produções, divididas entre filmes de longa-metragem, curtas-metragens, clipes e novelas. Dentre elas, os autores citam os filmes: Casa Verde (direção de Paulo Nascimento, 2008); Os Senhores da Guerra (direção de Tajara Ruas, 2013); Real Beleza (direção de Jorge Furtado, 2013); e O filme da minha vida (direção de Selton Mello, 2015) (Secretaria de Turismo e Cultura de Garibaldi apud Silveira \& Baptista, 2017).

Os autores apontam que a expansão da cidade como destino de produções audiovisuais é decorrente da ação da Garibaldi Film Commission, entidade criada em 2015, que vem atuando na atração e captação de novas produções (Silveira \& Baptista, 2017). Concluem que para o cinema dinamizar o turismo local, torna-se necessário o fomento de políticas públicas que contemplem os dois setores, bem como o desenvolvimento de uma rota cinematográfica na região como elemento diferencial de promoção turística (Silveira \& Baptista, 2017).

O quadro 06 sintetiza os principais achados dos estudos. 
Quadro 06 - Síntese dos estudos sobre turismo cinematográfico em cidades brasileiras

\begin{tabular}{|c|c|c|c|}
\hline AUTORES & OBJETIVO & $\begin{array}{c}\text { MÉTODOS } \\
\text { EMPREGADOS }\end{array}$ & PRINCIPAIS CONCLUSÕES \\
\hline Costa (2016) & $\begin{array}{l}\text { Analisar como o } \\
\text { turismo } \\
\text { cinematográfico pode } \\
\text { ser implementado em } \\
\text { Belém do Pará }\end{array}$ & $\begin{array}{l}\text { Pesquisa } \\
\text { bibliográfica, } \\
\text { exploratória, } \\
\text { qualitativa } \\
\text { indutiva. }\end{array}$ & $\begin{array}{l}\text { - Há amplas possibilidades para o turismo } \\
\text { cinematográfico em Belém do Pará, uma vez que a } \\
\text { cidade apresenta atrativos naturais, patrimoniais, } \\
\text { culturais capazes de atrair turistas e novas } \\
\text { produções audiovisuais. } \\
\text { Aponta como caminho a criação de uma film } \\
\text { commission atuante. } \\
\text { - Necessidade de articulação entre todos os atores } \\
\text { envolvidos (Governo Estadual, Municipal, agentes } \\
\text { do turismo, realizadores audiovisuais, sociedade, } \\
\text { etc.) para o desenvolvimento do turismo } \\
\text { cinematográfico em Belém do Pará. }\end{array}$ \\
\hline $\begin{array}{lr}\text { Duarte } & \& \\
\text { Fonseca } & \text { Filho } \\
(2016) & \end{array}$ & $\begin{array}{l}\text { Apresentar o } \\
\text { potencial da cidade } \\
\text { de Niterói-RJ para o } \\
\text { desenvolvimento do } \\
\text { turismo } \\
\text { cinematográfico. }\end{array}$ & $\begin{array}{l}\text { Levantamento de } \\
\text { atrativos turísticos } \\
\text { da cidade. Visitas } \\
\text { aos locais para a } \\
\text { realização do } \\
\text { registro fotográfico } \\
\text { e observação sobre } \\
\text { possíveis locações } \\
\text { para produções } \\
\text { audiovisuais. }\end{array}$ & $\begin{array}{l}\text { - Niterói pode diversificar o turismo por meio do } \\
\text { desenvolvimento do turismo cinematográfico, pois } \\
\text { possui variedade de atrativos que podem ser usados } \\
\text { como locação na cidade. } \\
\text { - Uma estratégia para captar produções audiovisuais } \\
\text { é a criação de incentivos fiscais, sendo este papel } \\
\text { representado pela Secretaria de Cultura do governo } \\
\text { do estado por meio da Rio Film Commission. } \\
\text { O catálogo de locações é uma ferramenta de } \\
\text { importância para a captação de produções } \\
\text { audiovisuais. }\end{array}$ \\
\hline $\begin{array}{l}\text { Souza \& Silva } \\
(2016)\end{array}$ & $\begin{array}{l}\text { Analisar a influência } \\
\text { do cinema para a } \\
\text { alavancagem do } \\
\text { turismoram } \\
\text { Cabaceiras }- \text { PB, a } \\
\text { partir da inserção do } \\
\text { município como } \\
\text { locação na produção } \\
\text { cinematográfica } \\
\text { nacional. }\end{array}$ & $\begin{array}{l}\begin{array}{l}\text { Pesquisa } \\
\text { exploratória, } \\
\text { natureza } \\
\text { quantitativa. } \\
\text { Aplicação } \\
\text { questionários. }\end{array} \\
\end{array}$ & $\begin{array}{l}\text { - O turismo e o cinema influenciam o } \\
\text { desenvolvimento de Cabaceiras, gerando } \\
\text { benefícios como melhorias de vias de acesso, } \\
\text { saneamento, pavimentação, saúde e educação. } \\
\text { Apesar dos turistas visitarem as locações } \\
\text { cinematográficas da cidade, não são motivados } \\
\text { pela aparição no cinema, não associando os } \\
\text { espaços visitados às produções cinematográficas } \\
\text { realizadas na cidade. } \\
\text { Existe uma relação entre turismo e cinema na } \\
\text { cidade, porém o turismo cinematográfico ainda não } \\
\text { é consolidado. }\end{array}$ \\
\hline $\begin{array}{l}\text { Silveira \& } \\
\text { Baptista (2017) }\end{array}$ & $\begin{array}{l}\begin{array}{l}\text { Abordar a relação } \\
\text { existente } \\
\text { entre }\end{array} \\
\text { tendoma e turismo, } \\
\text { análise a cidade de } \\
\text { Garibaldi, localizada } \\
\text { na Serra Gaúcha. }\end{array}$ & $\begin{array}{l}\text { Cartografia } \\
\text { Saberes: revisão } \\
\text { bibliográfica } \\
\text { levantamento das } \\
\text { produções } \\
\text { realizadas na cidade } \\
\text { caso de estudo. }\end{array}$ & $\begin{array}{l}\text { - O cinema pode ser uma forma de diversificar a } \\
\text { atividade turística, por meio das produções } \\
\text { realizadas no município. } \\
\text { - Garibaldi está desenvolvendo ações para atrelar } \\
\text { locações de produções audiovisuais à atividade } \\
\text { turística. } \\
\text { - Uma das estratégias para promoção do turismo } \\
\text { cinematográfico foi a criação de uma film } \\
\text { commission para a cidade. } \\
\text { Necessidade de fomento por meio de políticas } \\
\text { públicas que contemplem o turismo e o } \\
\text { audiovisual. } \\
\text { Necessidade de criar um roteiro turístico } \\
\text { cinematográfico, de modo a ser um elemento } \\
\text { diferencial na promoção turística. }\end{array}$ \\
\hline
\end{tabular}




\subsection{Turismo cinematográfico no Brasil: aportes a partir da produção científica nacional}

A análise da literatura nacional sobre turismo e cinema também buscou compreender a situação atual do desenvolvimento do turismo cinematográfico no país, com foco em duas questões principais: Quais destinos turísticos brasileiros ou produtos turísticos relacionados com turismo cinematográfico são mencionados na literatura nacional? Quais as principais perspectivas para o desenvolvimento do turismo cinematográfico no Brasil? Essas questões serão discutidas a seguir.

\subsubsection{As iniciativas brasileiras de turismo cinematográfico}

O turismo cinematográfico revela-se incipiente no país, restrito a poucas experiências relatadas nos artigos analisados. A literatura assinala a existência de poucas iniciativas de turismo cinematográfico em território brasileiro empreendidas nos últimos anos. O caso mais emblemático de destino turístico brasileiro a fomentar o turismo cinematográfico consiste na cidade de Cabaceiras (Paraíba).

Além do estudo de caso empreendido por Souza \& Silva (2016) especificamente sobre o turismo cinematográfico na cidade de Cabaceiras, Pereira Neto \& Schmidlin (2013) e Silveira \& Baptista (2017) citam a cidade como um importante exemplo de destino que aproveita o potencial das produções de cinema e televisão ali rodadas como meio para atração de visitantes. Os autores mencionam que a cidade vem servindo de cenário para diversas produções audiovisuais nacionais, com destaque para a série O Auto da Compadecida (que posteriormente foi editada para filme). Silveira \& Baptista (2017), ao citarem Nascimento (2009), mencionam a relevância desta série na projeção da localidade como destino turístico cinematográfico e destino de produções audiovisuais. Os autores ainda afirmam que fatores como a conservação do patrimônio arquitetônico e características climáticas (baixo índice pluviométrico e luminosidade) tornam a cidade atrativa para produções audiovisuais (Silveira \& Baptista, 2017).

Dentre as iniciativas empreendidas pelos agentes institucionais locais para fomento do turismo cinematográfico em Cabaceiras, tanto Pereira Neto \& Schmidlin (2013) como Silveira \& Baptista (2017) citam a criação de um letreiro "Roliúde Nordestina" de aproximadamente 80 metros de comprimento e 5 metros de altura, inspirado no de Hollywood, que passou a ser um atrativo turístico. Segundo Silveira \& Baptista (2017), tratou-se de uma ação mercadológica 
com fins de fomentar o turismo por meio de sua relação com o cinema. Souza \& Silva (2016) também citam a criação de um espaço museal dedicado às produções audiovisuais filmadas na cidade (Memorial Cinematográfico), tendo se tornado um atrativo turístico.

Segundo Souza \& Silva (2016) a motivação principal para visitação dessas locações não é a produção audiovisual em si, já que muitas vezes o visitante não a associa com um determinado atrativo. Assim, mesmo com as ações de promoção do turismo cinematográfico empreendidas pelos agentes institucionais locais e mesmo sendo Cabaceiras considerada um caso de referência nacional neste segmento, ainda não se pode afirmar que exista uma demanda consolidada de turismo cinematográfico.

Outra menção de destino turístico relacionado ao turismo cinematográfico consiste na cidade de Garibaldi, foco do estudo de caso realizado por Silveira \& Baptista (2017). Para os autores, a cidade gaúcha vem se destacando no cenário audiovisual nacional ao conseguir captar diversas produções audiovisuais (como filmes, novelas, videoclipes, etc.) e ao associar essas produções à criação de novos atrativos turísticos.

Dentre as iniciativas locais para fomento da relação entre turismo e audiovisual, Silveira \& Baptista (2017) mencionam a criação da Garibaldi Film Commission em 2015, o que contribuiu de maneira significativa para a captação de novas produções audiovisuais. Segundo os autores, a partir disso a gestão local vem atrelando as locações às iniciativas de promoção turística. Embora reconheçam a importância dessa ação, os autores acreditam que ainda é necessário instituir uma política pública para o turismo e o audiovisual, bem como seria importante a criação de novos produtos turísticos a exemplo de uma rota cinematográfica (Silveira \& Baptista, 2017).

Apesar de não ter sido objeto de um estudo de caso específico, a cidade do Rio de Janeiro é citada por Costa (2016) como o destino brasileiro que mais tem se beneficiado das imagens projetadas mundialmente em produções audiovisuais nacionais e internacionais, o que desperta o interesse pela visitação turística. Costa (2016) aponta que tais imagens despertam interesse de turistas por visitar locais como o Estádio do Maracanã, o bairro da Lapa, a Cidade do Samba e o calçadão de Copacabana.

Embora a veiculação e difusão de imagens turísticas do Rio de Janeiro pelas mais diversas produções audiovisuais (de telenovelas a filmes de Hollywood) seja um importante aspecto da relação de simbiose entre turismo e cinema, não se verificou nos artigos analisados quaisquer menção ao desenvolvimento do turismo cinematográfico na localidade. Ainda que a cidade tenha sido mencionada como um case de projeção internacional do imaginário turístico 
proporcionado pelo audiovisual, não se pode afirmar que o turismo cinematográfico já seja uma realidade na cidade, uma vez que a literatura não aponta nenhum tipo de iniciativa voltada para fomento deste segmento.

A cidade de Brasília, também embora não tenha sido objeto de um estudo de caso específico nos artigos analisados, é citada por Costa (2016) e Silveira \& Baptista (2017) como um exemplo de turismo cinematográfico no cenário nacional. Segundo Silveira \& Baptista (2017), a cidade já foi cenário de aproximadamente 200 filmes, dos quais cerca de 50 retratam a cidade como personagem ou protagonista da trama.

Ambos estudos mencionam a cidade como uma referência nacional em termos de turismo cinematográfico, selecionada pelo governo federal como um destino indutor do turismo cinematográfico em função de fatores como arquitetura diferenciada e cenário urbano. Silveira \& Baptista (2017) afirmam que o Ministério do Turismo conferiu à cidade as alcunhas de "Capital do Cinema" e "Cidade Referência do Turismo Cinematográfico". Costa (2016) enfatiza que a criação de uma film commission local em 1997 auxiliou no seu posicionamento como destino para produções cinematográficas e favoreceu a valorização turística da cidade.

Por fim, o estado do Tocantins é citado por Pereira Neto \& Schmidlin (2013) não especificamente como um destino de turismo cinematográfico, mas como um exemplo de localidade que criou um produto turístico a partir de uma produção audiovisual. A partir do filme Xingu (2012) rodado no estado, foi criado por uma agência de receptivo um roteiro turístico "Nas Trilhas do Cinema" que também abrangia outras locações usadas não apenas nesse filme, mas também em outras produções igualmente filmadas no estado, como o reality show americano Survivor Tocantins (2009) e o filme Deus é Brasileiro (direção de Carlos Diegues, 2003). (Pereira Neto \& Schmidlin, 2013).

\subsubsection{Perspectivas para o desenvolvimento do turismo cinematográfico no Brasil}

O turismo cinematográfico é um segmento que tem como matéria-prima principal o conjunto de produções audiovisuais rodadas em uma determinada localidade. Paisagens, edifícios históricos, edifícios contemporâneos, formações naturais, parques, praças, restaurantes, hotéis, estações de metrô, etc., que são retratados em qualquer tipo de produção audiovisual, como filmes, séries e telenovelas, viram recurso para serem convertidos em atrativos e experiências turísticas. Portanto, iniciativas que visem desenvolver o turismo cinematográfico devem vir acompanhadas de iniciativas para fomentar o setor audiovisual. 
Silveira \& Baptista (2017) consideram que a relação entre o setor turístico e o setor audiovisual é uma tendência em diversas regiões brasileiras. Os autores citam o estudo de Sinergia e Desenvolvimento entre as Indústrias do Turismo \& Audiovisual Brasileira (apud Silveira \& Baptista, 2017), lançado pelo Ministério do Turismo em 2007 para enfatizar o potencial turístico brasileiro e mencionar que estão em curso iniciativas de agentes institucionais públicos e privados para promover maior inserção do setor audiovisual no mercado internacional.

Como exemplos disso, Silveira \& Baptista (2017) e Costa (2016) assinalam as diversas iniciativas locais de criação de film commissions no território nacional, organizadas na Rede Brasileira de Film Commissions (REBRAFIC) que é uma associação sem fins lucrativos instituída com o propósito de apoiar produtores audiovisuais nacionais e internacionais, promover as regiões brasileiras como locações e disponibilizar informações das film commissions existentes. Os autores citam a existência da Bento Film Commission, Amazonas Film Commission, Bahia Film Commission, Balneário Camboriú Film Commission, Minas Film Commission, Ribeirão Preto Film Commission, Rio Film Commission, Santos Film Commission, São Paulo Film Commission e Garibaldi Film Commission, além de outras em processo de implantação.

Para Costa (2016), a criação de uma film commission atuante tem a capacidade de fortalecer e difundir a imagem da localidade e de promovê-la como um destino turístico. Souza \& Silva (2016) atribuem às film commissions o maior interesse de produtores nacionais e estrangeiros na realização de novos projetos audiovisuais em território brasileiro, uma vez que essas entidades vêm realizando ações de marketing, inclusive relacionadas com o turismo.

Quando se fala da importância das produções audiovisuais para fins de promoção turística no Brasil, não se pode perder de vista a amplitude que as telenovelas brasileiras alcançam no imaginário popular. Lima \& Silva (2019) citam dados da Pesquisa Brasileira de Mídia de 2015 para demonstrar a relevância das telenovelas: 95\% dos brasileiros costumam assistir à programação de TV, e desses, $73 \%$ acessam diariamente, o que favorece a construção de imaginários sobre destinos diversos.

Ainda que não se possa aferir o impacto direto desses números no fomento do turismo cinematográfico no Brasil, esse dado pode revelar um primeiro aspecto da simbiose entre turismo e audiovisual: as produções audiovisuais como difusoras da imagem turística de uma determinada localidade. Para Silveira \& Baptista (2017), as telenovelas têm projetado a imagem turística do país não apenas no território nacional, mas também no exterior. 
Nesse sentido, Lima \& Silva (2019) citam o caso da novela Pantanal (1990), cujo roteiro privilegiava o bioma das locações, permitindo ao espectador a construção de um imaginário turístico sobre a região do Pantanal. E mesmo quando o roteiro não inclui a localidade real das filmagens, ainda assim pode proporcionar a difusão de imagens sobre o destino turístico. Esse foi o caso da novela O Clone (2001), gravada nas dunas de Jenipabu (Rio Grande do Norte) para ambientar a região desértica do Marrocos. Segundo Lima \& Silva (2019), o ganho em visibilidade turística para a região de Jenipabu veio por meio de publicidade e matérias jornalísticas sobre a localidade em virtude do sucesso dessa produção audiovisual.

Para Silveira \& Baptista (2017) e Lima \& Silva (2019), as telenovelas consistem em um relevante fator de motivação de fluxos turísticos. Rio de Janeiro, Niterói, São Paulo, Tiradentes são exemplos de cidades que se beneficiaram com o sucesso de novelas e seriados da Rede Globo, de filmes para o cinema e filmes publicitários (Nascimento apud Silveira \& Baptista, 2017). Especificamente sobre o imaginário turístico criado em torno da favela brasileira, Godoy \& Luna (2012) afirmam que a produção audiovisual sobre a temática da favela também desperta o interesse turístico, tornando-a inclusive um destino de interesse internacional.

A relação entre turismo e cinema no país também é estimulada por meio de festivais de cinema, os quais, segundo Pereira Neto \& Schmidlin (2013), têm a capacidade de atrair turistas para o evento e de difundir a cultura e paisagens das regiões brasileiras por meio das produções exibidas nos festivais.

Souza \& Silva (2016) consideram que o Brasil possui uma grande vocação para o desenvolvimento do turismo cinematográfico, devido à sua pluralidade de culturas e etnias, às paisagens e à hospitalidade. Para Costa (2016), a relação do turismo com o cinema pode gerar alternativas para o incremento da demanda turística no país.

Como perspectiva positiva para o incremento do turismo cinematográfico no Brasil, Silveira \& Baptista (2017) apontam o desenvolvimento do setor audiovisual nacional experimentado nos últimos anos. Para os autores, a criação da Agência Nacional de Cinema (ANCINE), as leis de incentivo fiscais para o audiovisual, a busca pela modernização do setor e a valorização do cinema nacional pelo público são fatores que tornam o país um destino promissor para a produção audiovisual (Silveira \& Baptista, 2017).

O caminho para o fomento deste segmento no país perpassa a cooperação entre os setores público e privado. Silveira \& Baptista (2017) acreditam na importância do engajamento dos governos e da existência de uma rede de film commissions como vias para o fomento do setor audiovisual, gerando benefícios também para o setor turístico. Com iniciativas como essa, 
Körössy, N., Paes, R. G. dos S., \& Cordeiro, I. J. D. e. (2021, jan./abr.). Estado da arte sobre turismo e cinema no Brasil: uma revisão integrativa da literatura

Costa (2016) acredita que de forma tímida o turismo cinematográfico tem se configurado como uma opção mercadológica.

\section{Conclusões}

A revisão integrativa da literatura teve como principais fios condutores a busca por uma delimitação teórica sobre a relação entre turismo e audiovisual/cinema e a busca por informaçõess mais precisas sobre a situação atual do turismo cinematográfico no Brasil.

Verificou-se que os estudos sobre turismo e cinema no Brasil se concentram em três temáticas: o cinema (e/ou audiovisual) como vetor de imagem e promoção de destinos turísticos; estudos sobre imagem e representações de localidades em produções audiovisuais; e casos de estudo sobre turismo cinematográfico em cidades brasileiras.

Estudos acerca do cinema como vetor de imagem de destinos e estudos que envolveram análises de imagens e representações de localidades apontaram para a importância das produções audiovisuais (e a imagem por elas veiculada) enquanto meios de promoção turística. Defenderam que a capacidade de uma produção audiovisual em criar e difundir imagens sobre localidades pode ser somada aos esforços de promoção de destinos turísticos.

Alguns estudos chamaram a atenção para o fato de que a exibição de atrativos turísticos ou de outros equipamentos em produções cinematográficas tende a ocasionar um aumento no fluxo de turistas, tendo em vista que há pessoas que especificamente escolhem seus destinos de viagem após assistirem a filmes, séries, novelas e videoclipes. Quando existe um interesse específico em visitar localidades ou consumir produtos turísticos relacionados às produções audiovisuais, surge o chamado turismo cinematográfico.

Esse tipo de turismo é referenciado na literatura nacional como uma alternativa de diversificação da oferta turística local que traz benefícios econômicos advindos do aumento da visitação. É ponto comum nos estudos que o turismo cinematográfico, quando planejado, pode trazer benefícios, não apenas em termos de visibilidade do destino, mas também relacionados à criação de novos produtos turísticos. O turismo cinematográfico é tido como uma atividade que aproveita as potencialidades naturais, culturais, artísticas e gastronômicas de uma localidade. Enquanto uma prática social, deve ser retroalimentado por novas produções audiovisuais.

Considerando que a matéria-prima desse tipo de turismo se centra principalmente nas locações exibidas pelas produções audiovisuais, o seu desenvolvimento não requer apenas 
ações específicas de fomento da oferta de turismo cinematográfico (como a criação de movie maps, roteiros turísticos, parques temáticos, etc.), mas primeiramente demanda ações de fomento do setor audiovisual nacional e de captação de produções estrangeiras. Requer, portanto, cooperação entre os agentes dos setores turístico e audiovisual. Nesse sentido, apontase como caminho a atuação de agentes públicos e privados de ambos os setores e a criação de entidades como, por exemplo, as film commissions.

Sobre a situação atual do turismo cinematográfico no Brasil, os estudos revelaram o quanto ainda é tímido o desenvolvimento do turismo cinematográfico no país. Indicador dessa realidade é o baixo número de destinos com oferta de turismo cinematográfico citados nos artigos científicos nacionais. De toda a produção nacional analisada, apenas quatro estudos têm como foco o desenvolvimento do turismo cinematográfico em cidades brasileiras e, mesmo assim, se referem a destinos com oferta ainda incipiente. Tratam mais de possibilidades ou potencialidades do que efetivamente de um segmento já consolidado ou em expansão.

Ao mesmo tempo em que esses estudos apontam as potencialidades para o desenvolvimento tanto do setor audiovisual quanto do setor turístico (como paisagens exuberantes, hospitalidade do povo brasileiro, patrimônio histórico e cultural, etc.), revelam um baixo aproveitamento desse potencial para alavancagem do turismo cinematográfico.

Cabaceiras é o caso citado que mais se beneficia da relação entre o turismo e o audiovisual no Brasil, nacionalmente conhecido pelas diversas produções audiovisuais ali filmadas. Mesmo assim, Cabaceiras não é apontada pelos estudos como um caso consolidado de destino de turismo cinematográfico. Isso porque, embora seja cenário de diversas produções audiovisuais ao longo das últimas décadas, ainda não consegue transformar essa matéria-prima audiovisual em produtos turísticos relacionados ao turismo cinematográfico ou em ações promocionais de repercussão nacional.

Ao contrário de países como França, Reino Unido, Irlanda do Norte e Nova Zelândia que se destacam como destinos de referência no setor, o Brasil ainda não possui casos de repercussão nacional ou internacional. Apesar da expansão da produção audiovisual nacional nos últimos anos, o turismo cinematográfico ainda é tímido, caracterizado por poucas experiências empreendidas por organizações de gestão de destino e pela inexistência de bases de dados oficiais sobre o setor.

Por fim, conclui-se que as pesquisas nacionais sobre a relação entre turismo e cinema são escassas e incipientes. Especificamente sobre turismo cinematográfico, além de escassas, as pesquisas já realizadas não aprofundam questões relacionadas à organização da oferta de 
Körössy, N., Paes, R. G. dos S., \& Cordeiro, I. J. D. e. (2021, jan./abr.). Estado da arte sobre turismo e cinema no Brasil: uma revisão integrativa da literatura

turismo cinematográfico (como por exemplo, políticas públicas de fomento do setor, atuação de agentes públicos e privados, entraves para desenvolvimento do turismo cinematográfico), tampouco abordam questões ligadas à demanda por este segmento (motivações, expectativas e fluxos turísticos nas cidades investigadas). Tratam-se de lacunas téorico-empíricas que precisam ser preenchidas por pesquisas futuras a fim de contribuir para a discussão, ampliação e fortalecimento de experiências de turismo cinematográfico no país.

\section{Referências}

Azcue, J. D. (2014). Análisis e la Imagen de Destino a Través de la Cinematografía: Málaga. Dissertação de mestrado, Universidad de Málaga, Málaga, Espanha.

Atout France. (2014). Tourisme et Cinema - Comment dynamiser son territoire par l'audiovisuel. Paris: ATOUT France.

Beeton, S. (2010). The Advance of Film Tourism. Tourism and Hospitality Planning \& Development, 7(1), 1-6.

Beeton, S. (2006). Understaing Film-Induced Tourism. Tourism Analysis, 11, 181-188.

Beeton, S. (2000). It's a wrap! What happens after the film crew leaves? An examination of community responses to film-induced tourism. Trabalho apresentado no TTRA National Conference "Lights! Camera! Action!”, Burbank, CA,127-136.

Béric, D., Kovacevic, M., Simat, K. \& Bozic, S. (2013). Film Tourism: A contemporary resource for promoting Serbia. Turizam, 17 (1), 18-28.

Brasil, Mtur - Ministério do Turismo. (2007). Turismo Cinematográfico Brasileiro. Brasília: MTur, 2007.

Busby, G., \& Klug, J. (2001). Movie-induced tourism: The challenge of measurement and other issues. Journal of Vacation Marketing, 7(4), 316-332.

Carl, D., Kindon, S., \& Smith, K. (2007). Tourists' experiences of film locations: New Zealand as 'Middle-Earth.' Tourism Geographies: An International Journal of Tourism Space, Place and Environment, 9(1), 49-63.

Chen, C. Y. (2018). Influence of celebrity involvement on place attachment: Role of destination image in film tourism. Asia Pacific Journal of Tourism Research, 23(1), 1-14.

Connell, J. (2012). Film tourism evolution, progress and prospects. Tourism Management, 33(5), 1007-1029.

Costa, M. A. M. (2016). As possibilidades de implementação do turismo cinematográfico em Belém do Pará. Revista de Turismo Contemporâneo, 4(1),67-87. 
Di Cesare, F., \& La Salandra, A. (2015). Film induced, steps for a real exploitation in Europe. Almatourism - Journal of Tourism, Culture and Territorial Development, 6(4), 1-17.

Duarte, R., \& Filho, A. S. F. (2016). Luz, Câmera... Segmentação: uma proposta de turismo cinematográfico para a cidade de Niterói-RJ. Turismo em Análise, 27(2), 323-341.

Ercole, F., Melo, L. S., \& Alcoforado, C. L. (2014). Revisão Integrativa versus Revisão Sistemática. REME-Revista Mineira de Enfermagem, 18(1), 12-14.

Fonseca, J. F., \& Nunes, S. (2017). As características de um destino turístico reveladas através de uma produção cinematográfica e sua interligação com os consumidores. Marketing \& Tourism Review, 2(1), 1-29.

Freitas, R. F., \& Gotardo, A. T. (2018). Marcas do Rio pré-Olímpico: imaginários de sexo, violência e epidemias em um canal sino-americano do YouTube. Caderno Virtual de Turismo, 18(1), 40-52.

Godoy, K. E., \& Luna, S. B. (2012). A estética turística e cinematográfica da favela: suportes de uma autenticidade construída. Caderno Virtual de Turismo,12(2), 239-252.

Hudson, S. (2011). Working together to leverage film tourism: collaboration between the film and tourism industries. Worldwide Hospitality and Tourism Themes, 3(2), 165-172.

Hudson, S., \& Ritchie, J. (2006). Promoting destinations via film tourism: an empirical identification of supporting marketing initiatives. Journal of Travel Research, 44(4), 387396.

Irimias, A. (2015). Business Tourism aspects of film tourism: the case of Budapest. Almatourism - Journal of Tourism, Culture and Territorial Development, 6(4), 35-46.

Iwashita, C. (2008). Roles of films and television dramas in international tourism: The case of Japanese tourists to the UK. Journal of Travel \& Tourism Marketing, 24(2-3), 139-151.

Kim, H., \& Richardson, S. L. (2003). Motion picture impacts on destination images. Annals of Tourism Research, 30(1), 216-237.

Kim, S., \& Kim, S. (2017). Perceived values of TV drama, audience involvement, and behavioral intention in film tourism. Journal of Travel \& Tourism Marketing, 35(3), 259272.

Lima, A. F., \& Silva, M. J. V. (2019). Telenovelas brasileiras criando imagens e imaginários turísticos: o caso do destino Rio Grande do Norte. Revista Turismo - Visão e Ação, 21(1), 02-22.

Lopes, R. F; Nogueira, W. S; \& Baptista M. L. C. (2017). Imaginário, Cinema e Turismo: Uma Viagem por Clichês Culturais Associados ao Brasil, no Filme Rio 2. Revista Rosa dos Ventos, 9(3), 377-388. 
Lundberg, C., Ziakas, V., \& Morgan, N. (2017). Conceptualising on-screen tourism destination development. Tourist Studies, 18(2), 2017. 83-104.

Macionis, N. (2004). Understanding the film-induced tourist. In W. Frost; W. G. Croy, \& S. Beeton (Eds.), Proceedings of the International Tourism and Media Conference, Melbourne, 86-97.

Nascimento, F. M. (2009). Cineturismo. São Paulo: Aleph.

Nogueira, W. S; \& Lopes, R. F. (2017). A Amazônia em Rio 2: Clichês culturais cinematográficos para a promoção turística. Turismo \& Sociedade. Curitiba, 10(1), 1-18.

Pereira Neto, F. S.; \& Schmidlin, I. O. M. (2013). Turismo induzido por filmes: a imagem do Nordeste propagada pelo cinema brasileiro no ponto de vista do estudante de cinema no Ceará. PODIUM: Sport, Leisure and Tourism Review, 2(2), 01-31.

Polianskaia, A.; Rădut,, C.; \& Stănciulescu, G. C. (2016). Film Tourism responses to the tourist's expectations - new challenges. SEA - Practical Application of Science, 10, 149-156.

Qiao, F., Choi, Y., \& Lee, T. J. (2016). Assessing feasibility of film induced tourism: the case of Singapore. International Journal of Tourism Sciences, 16(3), 93-105.

Riley, R. W., \& \& Van Doren, C. S. (1992). Movies as tourism promotion: A “pull” factor in a "push" destination. Tourism Management, 13(3), 267-274.

Riley, R., Baker, D.; \& Van Doren, C. S. (1998). Movie induced tourism. Annals of Tourism Research, 25 (4), 919-935.

Santos, M. L; Alencar, D. G; \& Neves, S. G. (2018). As indústrias criativas de audiovisual e gastronomia no destino turístico Curitiba: uma análise do filme Estômago. Marketing \& Tourism Review, 3(1), 1-21.

Schofield, P. (1996). Cinematographic images of a city. Tourism Management, 17 (5), 333-340.

Silva, R. S. S. et al. (2011). Turismo e Cinema: Promoção Turística a partir do filme Sete Anos no Tibete. Rosa dos Ventos, 3(3), 368-381.

Silveira, V. N., \& Baptista, M. L. C. (2017). Turismo e cinema na Capital Nacional do Espumante - Garibaldi. Cenário, 5(8), 67-81.

Souza, L. A. V., \& Silva, M. J. V. (2016). Cabaceiras-PB Como Destino de Turismo Cinematográfico: Um Estudo Sobre a Interface Entre Turismo e Cinema. Revista Turismo Estudos e Práticas, 5(2), 186-218.

Tooke, N., \& Baker, M. (1996). Seeing is believing: the effect of film on visitor numbers to screened locations. Tourism Management, 17(2), 87-94.

Torraco, R. J. (2016). Writing Integrative Literature Reviews. Human Resource Development Review, 15(4), 404-428. 
Tuclea, C., \& Nistoreanu, P. (2011). How film and television programs can promote tourism and increase the competitiveness of tourist destination. Cactus Tourism Journal, 2(2), 25-30.

Vila, N. A., Brea, J. A. F., \& Garcia, A. F. (2012). Imagen y promoción de destinos termales a través de su emplazamiento en series audiovisuales. El caso de Ourense (España), capital termal. Turismo \& Sociedade, 5(2), 423-442.

Yasoshima, J. R. (2012). Gastronomia na Tela: As Representações da Comida no Cinema. Revista Rosa dos Ventos, 4(3), 300-316. 